\title{
REVIEW
}

\section{Discharged drilling waste from oil and gas platforms and its effects on benthic communities}

\author{
J. I. Ellis ${ }^{1, *}$, G. Fraser ${ }^{2}$, J. Russell ${ }^{3}$ \\ ${ }^{1}$ Coastal \& Freshwater Research Group, Cawthron Institute, Private Bag 2, Nelson 7010, New Zealand \\ ${ }^{2}$ Faculty of Environmental Studies, York University, Toronto, Ontario M6H 1T5, Canada \\ ${ }^{3}$ Alder Institute, Tors Cove, Newfoundland A0A 4A0, Canada
}

\begin{abstract}
This review paper identifies the main effects of oil and gas drilling waste on benthic environments. We identified 26 papers and technical reports that surveyed sediment samples from 72 production or exploration platform sites to assess the zone of influence of sediment contamination and biological effects on benthic communities. While oil-based fluids are now rarely used in the marine context, their release has had large-scale (out to $6 \mathrm{~km}$ ) and persistent (decadal time scale) impacts on benthic communities. The zone of influence of water-based drilling fluids as determined by sediment barium concentration was larger (2 to $20 \mathrm{~km}$ ) than for synthetic-based fluids (200 to $2000 \mathrm{~m}$ ). The zone of biological effects on benthic community diversity and abundance ranged from 100 to $1000 \mathrm{~m}$ for both water and synthetic fluids. Effects include changes in benthic species diversity, abundance and alterations to community structure. Functional changes included a loss of suspension-feeding species and increases in deposit feeders and polychaetes. In general, this review demonstrates a loss of benthic biodiversity and suspension-feeding communities due to oil exploration and production and the potential for large-scale effects on sensitive communities such as deep-sea, coral and vegetated habitats. Current research gaps and priorities are identified.
\end{abstract}

KEY WORDS: Benthic community composition - Chemical toxicity - Organic enrichment · Suspended sediments $\cdot$ Oil-based fluids $\cdot$ Synthetic-based fluids $\cdot$ Water-based fluids

\section{INTRODUCTION}

In 1935, the first offshore drilling structures were installed in the Caspian Sea. The largest offshore oil industry centres then appeared in the 1950s in the Persian Gulf, on the shelf of Venezuela, in the Gulf of Mexico and off the California (USA) coast (Patin 1999). Especially rapid and large-scale offshore oil and gas developments started in the 1970s with Great Britain, Norway, Italy, Malaysia, Indonesia and Australia numbered among the leading oil-producing countries (Patin 1999). Offshore development results in both exploration and development drilling operations, and it is the effects of drilling waste (spent drilling mud and drill cuttings) on the receiv- ing environment that has been identified as a primary environmental concern during drilling operations (Kingston 1992, Cranford et al. 2001).

There are 4 steps to drilling a well: (1) spudding in, (2) inserting a second string of casing, (3) installing a blow-out preventer and marine riser on top of the well head and (4) drilling the remaining sections of the well to discover oil reserves. 'Spudding in' involves forcing metal tubing called 'casing' into the ground. The second step includes drilling a deep hole inside the casing and then inserting a second casing into the freshly drilled hole. The 2 sections are cemented in place. The diameter and wall thickness of the pipes vary depending on well depth. Up until this point, any drilling fluids and cuttings are dis- 
charged directly at sea. The third step includes the installation of a blow-out preventer on top of the wellhead which controls formation pressures. Additionally, a marine riser is installed that allows all drilling fluids and cuttings to be pumped up through the riser and back to the oil platform or drilling ship. The remaining sections of the well are then drilled to reach the oil reserve.

Drill cuttings are produced by the grinding action of the drill bit and range in size from clay-sized particles to coarse gravel, having a mineralogy reflecting that of the drilled strata (Neff 1987, 2005, Trannum et al. 2010). Drilling muds lubricate the drill string, bring up cuttings from the well hole, control internal pressure and stabilize the well and constitute 5 to $25 \%$ of the discharged drill fluids (Trannum et al. 2010).

There are 3 main types of drilling mud: oil-based, synthetic and water-based fluids (OBF, SBF, WBF). In oil-based mud, the dominant fluid is a mineral oil; in synthetic mud it is ester, ether, acetyl or olefin; and in water-based mud, fresh or salt water is used. Drilling muds also contain a weighting material, clay or an organic polymer, various inorganic salts, solids and organic additives (Neff 2005). Barite $\left(\mathrm{BaSO}_{4}\right)$ has been the most frequently used weighting material. More recently, ilmenite $\left(\mathrm{FeTiO}_{3}\right)$, which has lower concentrations of trace metals such as mercury, lead and cadmium, is increasingly used as a replacement for barite (Neff 2005).

Because the casing, marine riser and blow-out preventer are not yet installed and the mud and cuttings cannot be returned to the platform for processing and disposal, drilling of the upper well sections is typically performed with less toxic seawater and bentonite $\left(\mathrm{Al}_{2} \mathrm{O}_{3} \cdot 4 \mathrm{SiO}_{2} \cdot \mathrm{H}_{2} \mathrm{O}\right)$, which are directly discharged at sea. For drilling the other sections, the types of drilling fluids used are well-specific. During the production phase of extraction, drilling fluids can be discharged directly into the marine environment, recycled and partially screened and discharged, reinjected or shipped to shore for land disposal, depending on national regulations. This review considers effects of discharged drilling fluids from both exploration and production wells.

We reviewed scientific papers and unpublished technical reports to summarize the key findings associated with the effects of drilling activities on seafloor communities. The effects associated with OBF, SBF and WBF on benthic communities are summarised using data from Australia, Canada, Italy, Norway and the USA. Most of the publications and technical reports present compliance data collected as part of an environmental effects monitoring (EEM) programme required by the various jurisdictions in which the industry is operating. EEM programmes allow for the verification of environmental effects predictions and the analysis of the effectiveness of mitigative measures but may also identify unforeseen environmental problems that may arise and address them in an effective and timely manner (Duinker 1989). Sediment quality, benthic habitat and communities and fish health are routinely monitored for drilling EEM programmes (e.g. Husky Oil Ltd 2000). Macrobenthic communities are widely used to monitor the effects of marine pollution because certain benthic organisms are sessile and integrate effects of pollutants over time (Gray et al. 1990). This review provides a synthesis of the current knowledge of the effects of oil and gas exploration and production from drilling activities on seafloor communities.

\section{METHODS}

We conducted a literature search using combinations of the following terms: 'benthic', 'environmental effects', 'drilling fluids', 'oil' and 'gas', 'production drilling' and 'exploration drilling', using the Web of Science. The search included journals published from 1902 up until the year 2010. We also conducted separate searches for unpublished technical reports. Surprisingly few findings have been published in the open scientific literature on the effects of drilling fluids from platform operations due to the proprietary nature of the data (Olsgard \& Gray 1995). Most of the data on the outcomes of research or EEM programmes on the effects of drill cuttings remain confidential to the respective country's environmental authorities or industry, with Norway being an exception. Norway has an open policy whereby all data reported to the Norwegian State Pollution Control Authority are available to the public (Olsgard \& Gray 1995). As a result, many studies currently available in the open scientific literature are based on data collected around platforms in Norway. However, in 2000 the U.S. Environmental Protection Agency (EPA) published a review of surveys that assessed water- and synthetic-based drilling fluids primarily from the USA Continental Shelf, the Gulf of Mexico and the North Sea. The review included survey information available from the open literature, technical reports and comments submitted to the EPA as rulemaking records. The review, which was used to develop effluent limitations guidelines and stan- 
dards, provides a valuable source of information not available in the open literature but present in unpublished technical reports. Some of the reports summarized by the EPA were not available publicly, and our requests for the individual reports were denied. In these cases, we had to rely on the summary information provided in EPA (2000).

From our literature search, we identified 26 papers and technical reports that surveyed sediment samples from 72 production or exploration platforms that could be used to assess the zone of influence of sediment contamination and biological effects. One region-wide study reviewed data from a field of 200 wells in the southern Gulf of Mexico (Hernandez Arana et al. 2005). Most sampling designs employed a radial gradient sampling design recommended for point source pollution (Ellis \& Schneider 1997), including one or more far-field reference stations, and in some programmes, baseline and several postdrilling surveys were sampled dependent on the nature of the field. Often, a number of transects radiating away from the platform with sites at varying distances would be sampled. The basic design used in the Norwegian sector is a cross, which intersects at the centre of the field with sampling stations placed at geometrically increasing distances from the centre (e.g. 250, 500, 1000, 2000, 4000, 6000 m; see Gray et al. 1990, Olsgard \& Gray 1995) (Fig. 1). One axis is usually located along the dominant current, and one or more reference stations are located at distances such as $12 \mathrm{~km}$. Sediment core samples to quantify physical and chemical variables are taken to determine sediment grain size, organic carbon content and heavy metal contamination. Heavy metal analyses routinely determine $\mathrm{Fe}, \mathrm{C}, \mathrm{Zn}, \mathrm{Ba}, \mathrm{Sr}, \mathrm{Cd}, \mathrm{Cr}$ and $\mathrm{Hg}$ levels. Benthic macrofauna are determined from grab samples such as $0.1 \mathrm{~m}^{2}$ van Veen grabs and box corers sieved using a 0.5 or $1 \mathrm{~mm}$ mesh. Benthic meiofauna are typically determined from multi-core samples (e.g. $<0.01 \mathrm{~m}^{2}$ ) sieved using a $64 \mu \mathrm{m}$ or smaller mesh. Benthic epifauna are determined from still camera and video imagery. The type of sampling method used is dependent on the habitat. Some studies also determined body burden levels of heavy metals in tissue samples. In reviewing EEM programmes, we recorded the distance from the production or exploration platform of elevated hydrocarbons, barium and other chemicals. We also summarized changes in benthic communities with distance from platforms, such as abundance, diversity, biomass, species composition or the presence and absence of rare species. Biological information is often presented as the distance of a change in a variable (e.g.

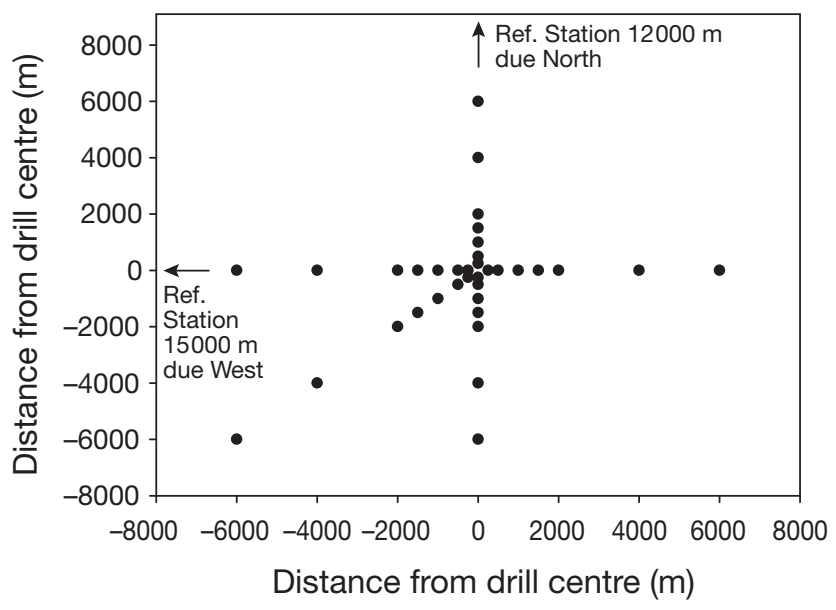

Fig. 1. Sampling design layout commonly used in environmental effects monitoring programmes where sediment and biological samples are taken with distance from drill centres in marine environments. Additional axes (e.g. diagonal axis running southwest in the panel) are often aligned with the predominant currents

abundance, diversity, community composition) relative to background levels (Olsgard \& Gray 1995). Background levels are determined from pre-drilling surveys or from far-field reference sites. We also included any information associated with bioaccumulation of heavy metals. Some papers and technical reports also documented the spatial extent of physical or biological effects over time as production activities increased or as wells were decommissioned. Physical effects are related to changes in the sediment grain size and heavy metal accumulation while biological effects are related to changes in benthic communities. In such cases, we included changes in the scale of effects, potential for cumulative impacts with increasing drilling discharge and temporal scales of community recovery. These summary statistics are provided for oil, synthetic and water drilling fluids separately in order to increase our understanding of the environmental effects associated with various drilling programmes.

\section{RESULTS}

For all fluid types (OBF, WBF, SBF), the degree of effects of drilling fluids on benthic and demersal species is highly dependent on a number of local environmental variables (e.g. depth, current and wave regimes, substrate type), and on the nature and volume of the discharges (cutting size, outfall location in water column). However, consistent zones of detection for drilling fluids and biological effects for $\mathrm{OBF}$, 
WBF and SBF were documented and are summarized below.

\section{Oil-based fluids}

Data from 5 technical reports and scientific papers summarizing effects from OBFs in 16 fields in the North Sea are provided in Table 1. Most of the early knowledge about OBFs and cuttings discharge was developed from seabed studies conducted on North Sea sites. Operations began in the 1970s using diesel OBFs. The zones of detection for drilling fluids and biological effects for OBFs varied for development versus single-well operations. In general, elevated barium and total hydrocarbon concentrations in sediment samples ranged from 2000 to $6000 \mathrm{~m}$ from the platforms before reaching background levels. Spatial trends show hydrocarbon, barium and trace metal concentrations decreasing with distance from the drill sites. Biological effects, including changes in community composition, were documented from 500 to $6000 \mathrm{~m}$ (Fig. 2). Specific studies that document varying levels of chemical and biological effects are discussed in the following paragraphs.

Davies et al. $(1984,1988)$ summarized various zones of influence where maximum ranges of chemical and biological effects were distinguished for development and single wells in the North Sea. The authors concluded that chemical tracers associated with development wells could be documented out to distances ranging between 800 and $4000 \mathrm{~m}$. They also noted a transition zone in benthic diversity and community structure that could occur between 200 and $2000 \mathrm{~m}$ from platforms. Close to the cuttings discharge was an area with few or no macrobenthic species, although diversity increased rapidly with distance until background species diversity was encountered between $\sim 200$ and $2000 \mathrm{~m}$, depending on the oceanographic characteristics and operational history at the particular location. Davies et al. (1988) interpreted the diversity gradient as a classic successional response to disturbance as described by Pearson \& Rosenberg (1978), with a peak of opportunist deposit-feeding polychaete species occurring between the severely depleted zone and the progressively more diverse zone farther away from the discharge.

Studies of long-term effects indicate that the aerial extent and magnitude of effects of OBF cuttings discharge on benthic communities are highly variable. Olsgard \& Gray (1995) documented the persistence of sediment contamination over a period of 6 to $9 \mathrm{yr}$

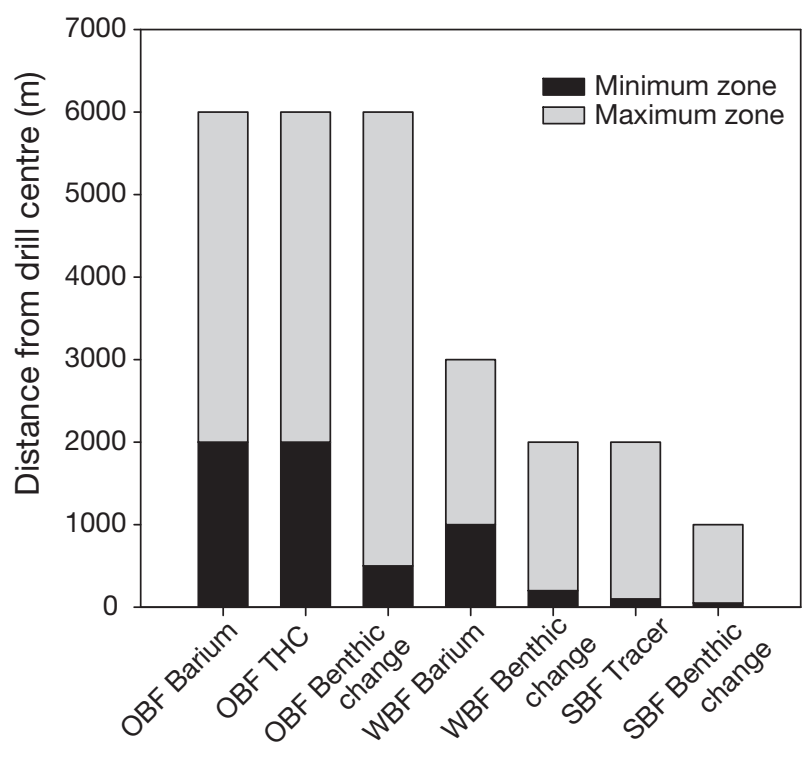

Fig. 2. Maximum and minimum extent of increases or decreases in physical and biological variables from the drill centre in relation to background levels. These 'zones of effects' are identified from all studies reviewed and provide the range of distances reported in the literature. OBF: oilbased fluid, WBF: water-based fluid, SBF: synthetic-based fluid, THC: total hydrocarbon content

after termination of cuttings discharge for 3 oil fields on the Norwegian continental shelf. Nearly all stations located 2000 to $6000 \mathrm{~m}$ from the drill site showed evidence of elevated barium and total hydrocarbons and sometimes also elevated levels of zinc, copper, cadmium and lead, even after 9 yr. Effects on the fauna several years after cessation of drill-cutting discharges ranged between 1000 and $6000 \mathrm{~m}$ from the platform, with only a few contaminated stations at each field not exhibiting faunal effects. Thus, the areas where biological effects were detected were only slightly smaller than the contaminated areas. Sites that were severely polluted were characterised by low diversity and the presence of opportunistic polychaete species. Multivariate analyses linking fauna and environmental variables indicated that pollution effects on community composition were mainly related to the total hydrocarbon content (THC), barium and strontium concentrations, but also to metals like zinc, copper, cadmium and lead. Subsequent to the cessation of discharges, biodegradation of oil and reduced concentrations of THC were observed. Effects on the fauna closely followed the patterns of contamination, including an increase in the spatial area around the platforms where the fauna was affected several years after cessation of drill-cutting discharges. Olsgard \& Gray (1995) con- 


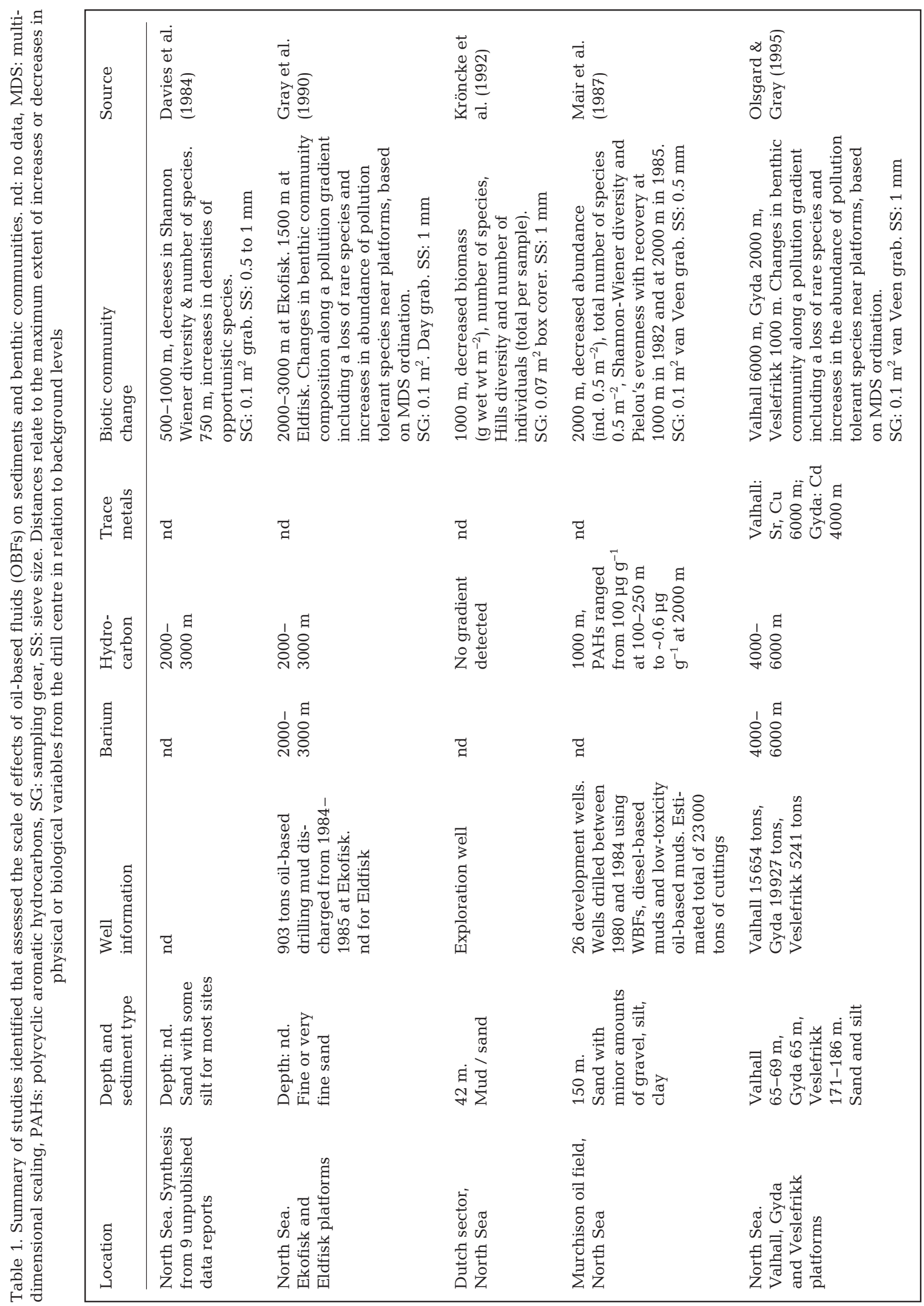


cluded that effects on benthos persisted longer than the ambient hydrocarbon levels were actually elevated, suggesting that metals or other components of the drill cuttings were also contributing to long-term biological effects. Results from the Dutch North Sea monitoring programme also indicated that localized hydrocarbon contamination and biological effects were detectable as long as $8 \mathrm{yr}$ after drilling (Daan et al. 1996).

As a result of these studies, the use of OBF cutting discharge release was phased out in the 1990s for the North Sea, although OBFs are still used in difficult drilling conditions, under strict regulation (Hurley \& Ellis 2004). The work from the North Sea also informed the regulations of OBFs in the other regions considered in this review. For example, in Canada, low-toxicity mineral oils (LTMOs) were last used in 1989 off Newfoundland and in the mid-1990s off Nova Scotia and the Beaufort Sea (Hurley \& Ellis 2004). Oil and gas exploration and development drilling programmes now generally use WBFs and SBFs.

\section{Water-based fluids}

Data from 14 scientific papers and technical reports summarizing effects from WBFs are provided in Table 2. These papers represent data from 41 wells and 1 region-wide study of 200 wells. The minimum and maximum distances of changes in physical and biological variables relative to background values are also summarized in Fig. 2. For example, the WBF barium column provides the range of reported distances of elevated barium concentrations in sediment around wells discharging WBFs. In general, elevated barium concentrations in sediment samples ranged between 1000 and $3000 \mathrm{~m}$ from the platforms before reaching background levels. Biological effects, including changes in community composition, were documented from 250 to $2000 \mathrm{~m}$ (Fig. 2). Specific studies discussed in the following paragraphs document varying levels of chemical and biological effects.

The most clearly documented point source effects of these discharges include alterations in the concentration of barium in sediments. Observations of the zone of detection of WBF for both single- and multi-well facilities, using barium as a tracer for drilling fluids, suggest that average measured background levels are reached at 1000 to $3000 \mathrm{~m}$ (Houghton et al. 1980, Mariani et al. 1980, Meek \& Ray 1980, Menzie et al. 1980, Ray \& Meek 1980, CSA 1986, Boothe \& Presley 1989, Jenkins et al. 1989)
(Table 2). However, drilling fluid solids can be transported over longer distances to regional areas of deposition, albeit at low concentrations, based on a study of 8 exploration wells located on the Georges Bank, Atlantic USA, in 80 to $140 \mathrm{~m}$ depths (Bothner et al. 1985, Neff et al. 1989). Barium was detected in the fine fraction of sediment $65 \mathrm{~km}$ west (downstream) and $35 \mathrm{~km}$ east of an exploratory drilling site after drilling was completed, with resuspension of drilling mud barite being identified as an important sediment transport mechanism (Bothner et al. 1985).

Increases in a suite of other trace metals associated with WBFs (As, Cd, Cr, Cu, Hg, Pb, Zn) have also been observed. These increases were more spatially limited (generally within 250 to $500 \mathrm{~m}$ of the drill site), when compared to the scale of detection for barium concentrations. However, increases in trace metals (specifically $\mathrm{Cr}$ ) were detected between 1000 and $2000 \mathrm{~m}$ from the drill centre for sites on the Gulf of Mexico at depths ranging from 76 to $160 \mathrm{~m}$ (CSA 1986). At deeper-water sites (>80 m), a comparison of metal enrichments immediately after cessation of drilling and 5 to $10 \mathrm{yr}$ after the last discharges showed that similar concentrations were observed, confirming the relative stability of the contaminant field over time frames of years, possibly decades, at deeper sites (Kennicutt et al. 1996).

Biological effects have been detected at distances of 200 to $2000 \mathrm{~m}$ (US DOI 1977, Lees \& Houghton 1980, Menzie et al. 1980, Montagna \& Harper 1996, Green 2003). Alterations to benthic community structure are virtually always observed within $300 \mathrm{~m}$ of the drill site. Effects include a reduction in species diversity and increases in the abundance of a few opportunistic species. Functional changes were also observed, including a loss of suspension-feeding species and increases in deposit feeders. Changes have been ascribed to physical alteration in sediment texture and organic enrichment effects more frequently than to toxic effects. However, systematic studies of the relative contribution of varying stressors to observed effects have not been conducted. Sedimentation can be very high near oil and gas rigs because drill cuttings tend to settle onto the seabed when discharged directly at sea. The new sediment composition reflects the grain size of the drill cuttings and not the overlying sediments. Organic enrichment occurs due to the addition of usable carbon to the ecosystem (see Patin 1999). The total quantity of oil discharged by the offshore industry via cuttings, produced waters and accidental spills can be high, representing inputs of carbon into the marine environment. For example, in the North Sea the total oil input from 


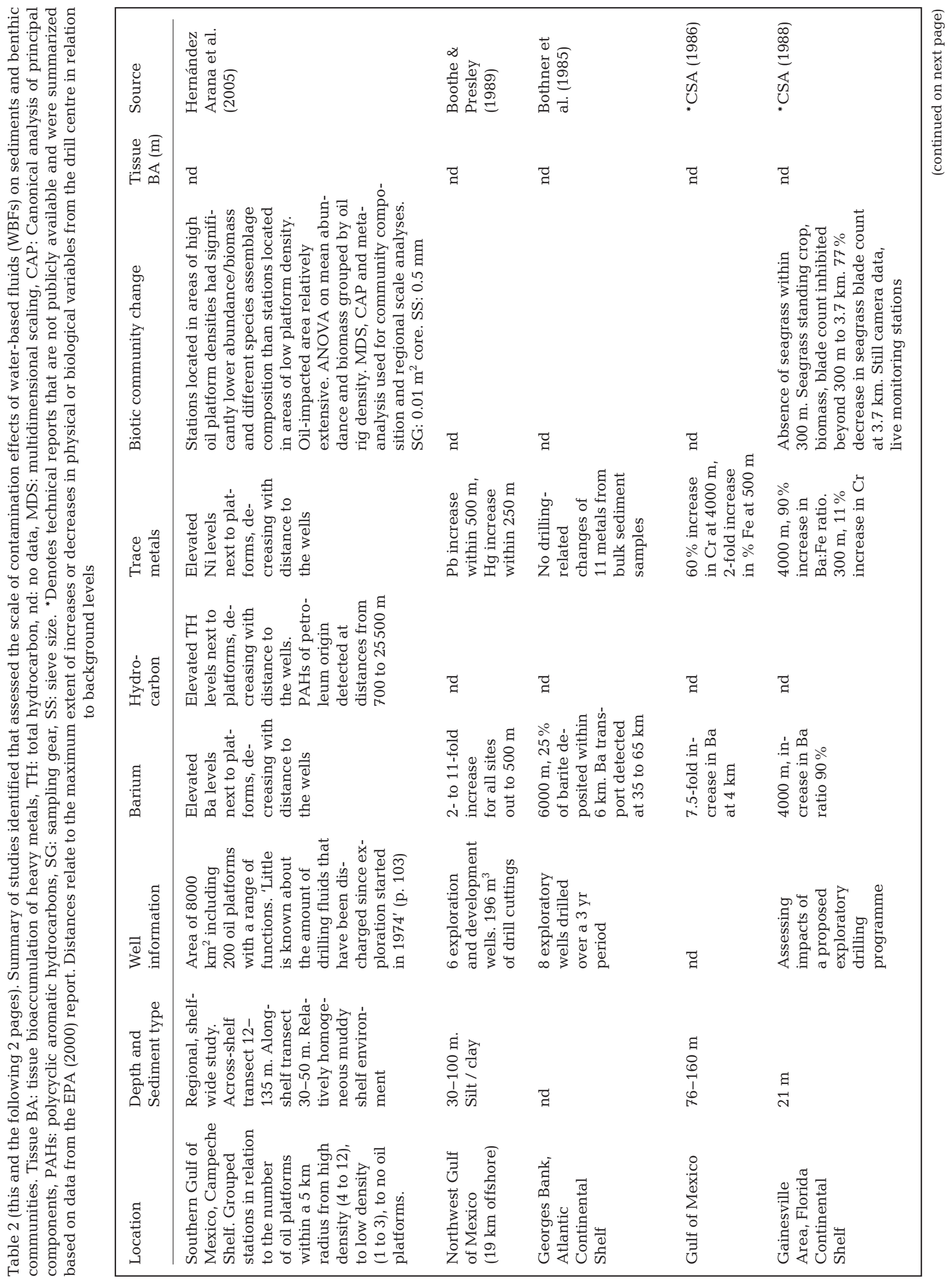




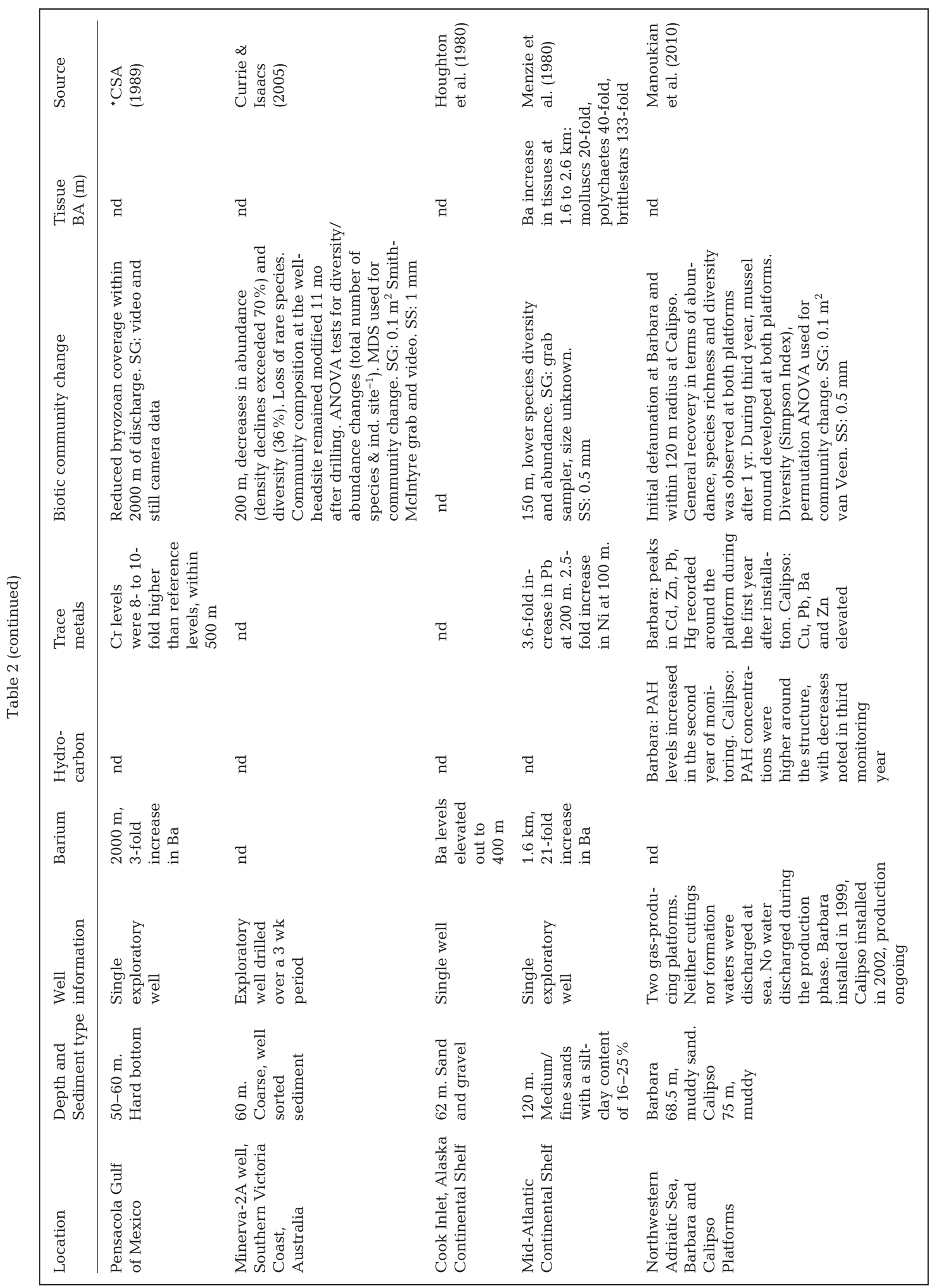




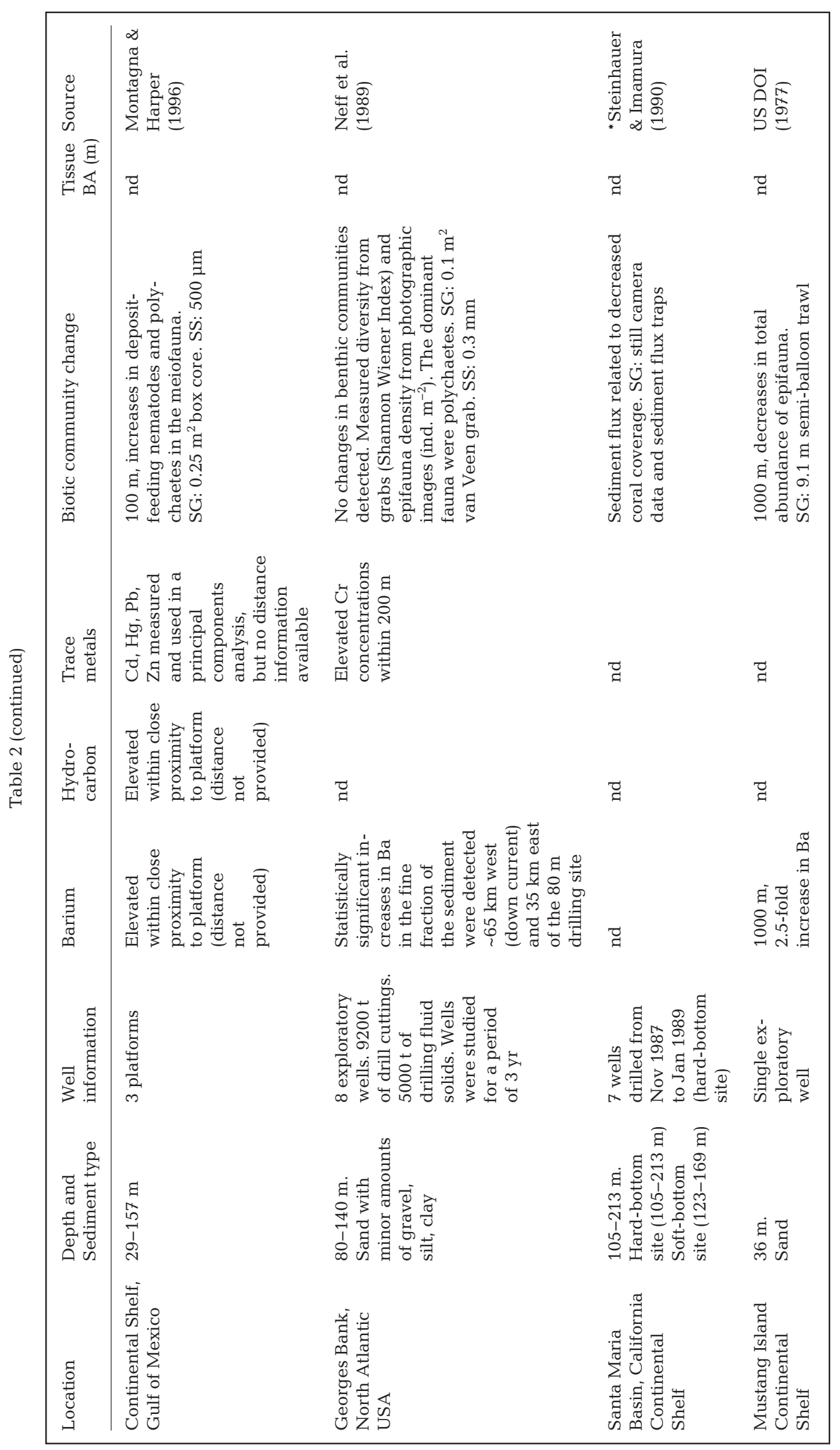


these sources in 1990 was estimated at $20000 \mathrm{t} \mathrm{yr}^{-1}$ (Patin 1999).

The greatest biological effects of WBFs were documented for sensitive seagrass communities and hardbottom communities. Data on seagrasses are limited to a single shallow-water USA study (CSA 1988) which documented a greater spatial scale of biological effects than studies conducted on unvegetated soft-sediment habitats. Approximately 9 wk after drilling operations commenced, seagrasses were completely absent within $300 \mathrm{~m}$ of the drill site. At a distance of $3700 \mathrm{~m}$ from the drill site, blade biomass and blade numbers showed only $25 \%$ growth compared to the increases shown at the reference station (CSA 1988).

Two case studies also documented effects out to greater spatial scales for hard-bottom epibenthic habitats (CSA 1989, Steinhauer \& Imamura 1990) than the spatial scale of effects documented for soft-bottom habitats. The first study documented reductions in epibenthic community coverage that occurred out to $2000 \mathrm{~m}$ from a single exploration well (CSA 1989). This field survey used photographic and video data to detect community change, whereby total biotic coverage of epibenthic communities decreased by $55 \%$ between pre- versus post-drilling surveys. Reference station values decreased in total biotic coverage by $19 \%$ between survey times. Overall decreases at both drill site and reference stations were primarily due to dramatic (i.e. $95 \%$ ) decreases in bryozoan coverage between surveys. Because only 1 pre- and 1 post-drilling survey were conducted, it is more difficult to separate out effects related to natural variability over time, compared to changes in community composition with respect to drilling activities; however, the report does provide evidence for drilling-related effects on sensitive hard-bottom epibenthic communities. A second study that also collected photographic information for a hard-bottom habitat provided evidence that increased sediment flux from drilling activities was related to decreased coral coverage for the solitary cup coral Caryophyllia sp. (Steinhauer \& Imamura 1990). The zones of effects for these 2 studies that represent sensitive communities were larger than for soft-bottom infaunal benthic communities.

Besides documented changes in species composition or abundances, another impact on benthic communities was associated with chemical toxicity as measured by body burden. Elevated concentrations of barium in tissues of polychaetes, brittle stars (primarily Amphioplus macilentus) and bivalves (primarily Lucinoma filosa) were detected as far as $1600 \mathrm{~m}$ from a single well discharging WBFs (Menzie et al. 1980). These species cover a range of trophic modes including detritivores (brittle stars) as well as deposit- and suspension-feeding modes.

A region-wide study provides information on the potential for cumulative effects where multiple wells are drilled in an area (Hernández Arana et al. 2005). In the southern Gulf of Mexico, a regional shelf-wide study was conducted that sampled across an $8000 \mathrm{~km}^{2}$ area that included 200 oil platforms with a range of functions. Little is known about the amount of drilling fluids and produced water that have been discharged since oil exploration started in 1974. The objective was to determine the effect of oil-related activity in a region known to have a highly variable benthic community composition due to temporal and spatial variability of its natural environment. A transect design along gradients of natural variables and disturbance intensities, including active oil platforms, was implemented during the rainy and winter storm seasons of 1999 to 2000 . Two transects running across the shelf and 2 running along the shelf were sampled. Twelve stations were allocated along each transect, with a total of 48 stations sampled in the study. Contamination from oil-related activities extended beyond the immediate surroundings of the point source. Results from ordination analysis clustered stations with high concentrations of oil hydrocarbon and metals together, independent of season, and these stations did not exhibit the ambient pattern of depth and grain-size gradients across and along the shelf. Specifically, the study grouped stations in relation to the number of oil platforms within a radius of $5 \mathrm{~km}$ from high density (4 to 12), low density (1 to 3 ) and no oil platforms and was able to demonstrate elevated barium and hydrocarbon concentrations with polycyclic aromatic hydrocarbons (PAHs) of petroleum origin detected at distances ranging from 700 to $25500 \mathrm{~m}$. Stations located in areas of high oil platform densities, or close to oil-related activities, had significantly lower abundance or biomass and different species composition than those stations located in areas of low platform density or farther away from oil-related activities (Hernández Arana et al. 2005). These effects were generally independent of natural differences between the sampling dates. The authors also used an index of multivariate dispersion that indicated increased variability in benthic community composition for the group of stations located within 0 to $3 \mathrm{~km}$ of an oil field, indicating increased levels of stress (Warwick et al. 1990, Warwick \& Clarke 1993). Finally, for all 48 stations sampled, a fossil fuel pollution index was measured and 
demonstrated that 12 stations sampled in 1999 and 19 stations sampled in 2000 had PAHs of petroleum origin. The nearest distance to oil platforms for these stations ranged from 1300 to $22500 \mathrm{~m}$ for stations in 1999 and 700 to $25500 \mathrm{~m}$ for stations in 2000, indicating that the distance of effects for petroleum origin hydrocarbons could range out to $25.5 \mathrm{~km}$. It was therefore concluded that oil-related activities in the southern Gulf of Mexico have a significant effect on the macrofaunal assemblages and that effects are comparatively extensive and occur at a regional scale (Hernández Arana et al. 2005).

Little information is available on recovery time scales for benthic habitats after exposure to WBFs. The few studies of benthic community change around single wells suggest that communities returned to baseline conditions $1 \mathrm{yr}$ after the cessation of drilling (Currie \& Isaacs 2005, Manoukian et al. 2010). In some cases, sensitive species, such as the burrowing brittle star Amphioplus macilentus, remained depressed $1 \mathrm{yr}$ after drilling (Menzie et al. 1980). Currently, there is limited information on recovery time scales, as multiple wells operate in a region.

\section{Synthetic-based fluids}

Seven studies summarizing information from a total of 15 wells were reviewed to assess environmental effects associated with SBFs. The area of detection and scale of biological effects resulting from discharged SBFs were smaller than that resulting from the release of WBFs. Maximum concentrations of synthetic tracers from SBFs in sediment were detected at distances ranging from 100 to $2000 \mathrm{~m}$ from the discharge location (Tables $3 \& 4$ ). Biological effects associated with the release of SBF cuttings were generally detected at distances of 50 to $500 \mathrm{~m}$ from well sites (Smith \& May 1991, Candler et al. 1995, Schaanning 1995, DeBlois et al. 2005), although reductions in the abundance of a few taxa (such as bivalves and echinoderms) were detected out to $1000 \mathrm{~m}$ (Daan et al. 1996; Table 3). Jensen et al. (1999) documented effects of various SBFs (ester, ether, olefin) on benthic community abundance and diversity (Table 5). Their study was based on previously collected field data from biological and chemical surveys of 9 oil and gas fields in the North Sea and the Norwegian Sea. The maximum distance with reduced number of species ranged from 250 to $500 \mathrm{~m}$, while the maximum change in abundances of benthic organisms was typically 500 to $1000 \mathrm{~m}$
(Table 5). The change in the density of individuals up to $1000 \mathrm{~m}$ was generally due to changes in the abundance of indicator species such as the polychaetes Chaetozone setosa, Capitella capitata, Pseudopolydora paucibranchiata, Raricirrus beryli and Octobranchus floriceps. The authors also compared the zone of effects of different SBFs on benthic communities. Statistically significant correlations were found between reduced diversity in the benthic fauna and high concentrations of barium, olefin and ester in the bottom sediments surrounding several fields (Jensen et al. 1999). In most cases, there was a stronger correlation between the reduction in diversity and high concentrations of olefin and/or ester than with barium, which may indicate that possible toxic and anoxic effects are greater than effects due to sedimentation and physical disturbance as a result of dispersion of cuttings and barium.

Research on SBFs suggests that changes in benthic communities occur primarily due to the level of nutrient enrichment from synthetic materials and the ensuing development of benthic anoxia. Specifically, organic enrichment causes oxygen depletion due to the biodegradation of the discharged SBFs. This biodegradation results in predominantly anoxic conditions in the sediment (EPA 2000). All synthetic fluids have high theoretical oxygen demands and are likely to produce a substantial sediment oxygen demand when discharged in the amounts typical of offshore drilling operations. The actual oxygen demand of a compound will depend on the biodegradability of the compound and the specific organisms metabolizing the compound. Existing field data suggest that these materials will be substantially degraded on a time scale of 1 to a few years; however, the distribution and fate of these materials has not been extensively documented (EPA 2000). The relative impact of the various types of SBFs is also speculative given the paucity of field data for laboratory versus field conditions (EPA 2000). Further research on biological effects of SBFs, recovery trajectories and effects associated with differing SBFs is required.

\section{RESEARCH GAPS AND RECOMMENDATIONS}

The extraction of fossil fuels from offshore fields has increased rapidly in the last 5 decades, becoming the leading activity in the exploitation of marine mineral resources. As a result, thousands of offshore platforms have proliferated over the world's oceans, and more will likely be implemented in the future 


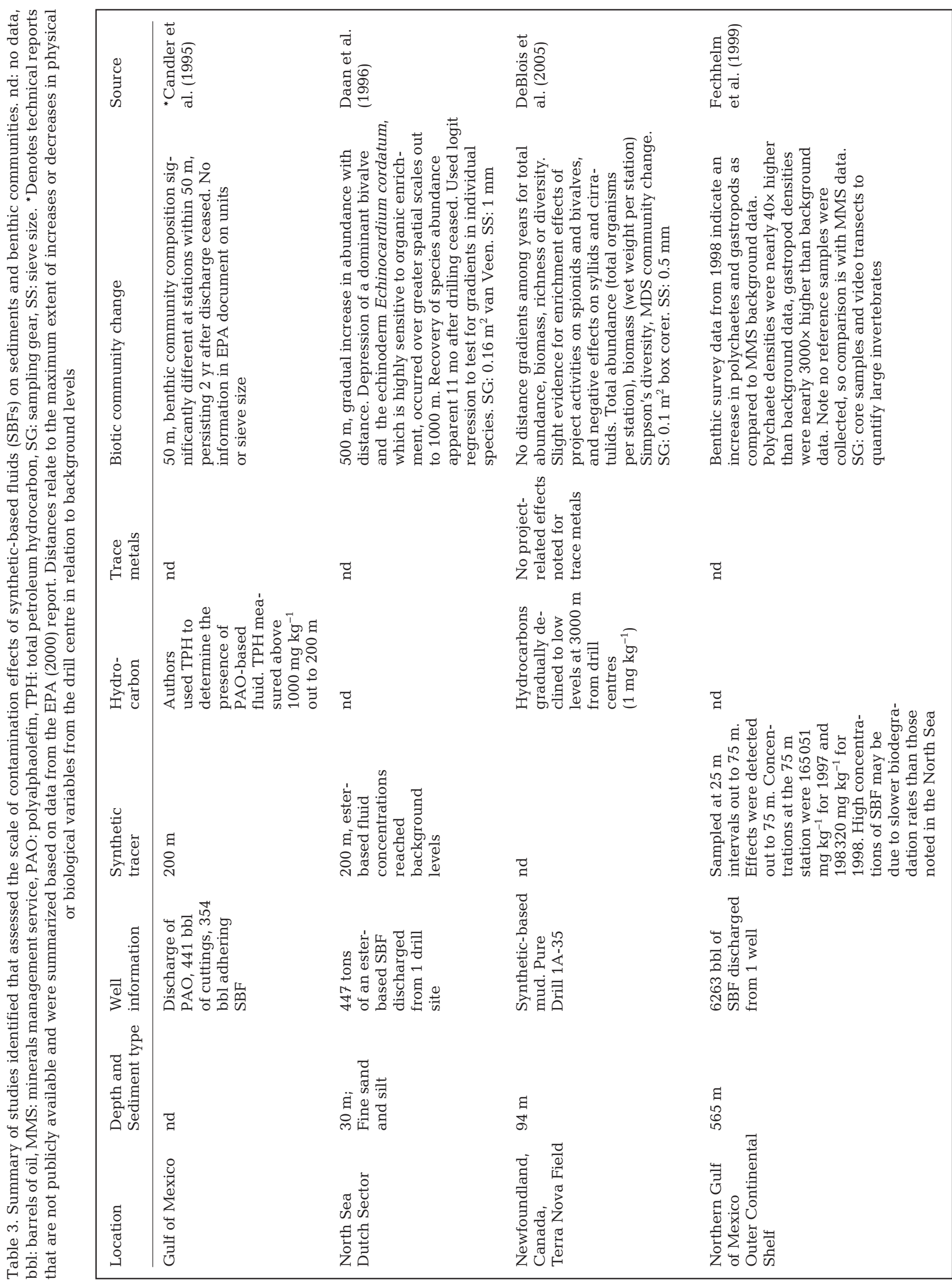




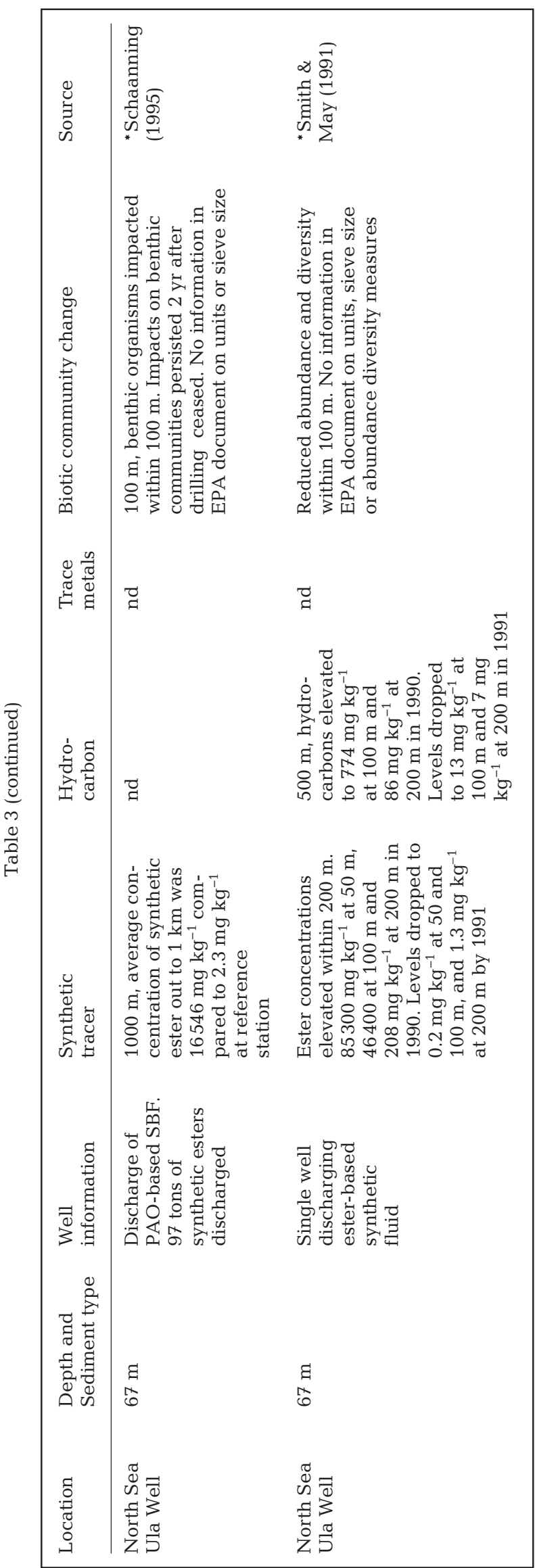

(Pulsipher \& Daniel 2000), representing a threat for coastal, shelf and deep-sea systems (Terlizzi et al. 2008). The magnitude of effects on benthic assemblages varies depending on the complex interactions among local environmental factors and specific features of platforms (Terlizzi et al. 2008). In summary, the use of OBFs has been phased out for most marine drilling programs due to the large spatial extent of biological effects (up to $6000 \mathrm{~m}$ ) and documented recovery trajectories of up to 8 yr (Olsgard \& Gray 1995, Hurley \& Ellis 2004). For WBFs and SBFs, the maximum zone of benthic effects ranged from 50 to $1000 \mathrm{~m}$ from platforms or wells depending on discharge volumes of drilling fluids, hydrodynamic regimes, water depth and the sensitivity of benthic habitats within the region. The scale of documented effects on hard-bottom benthic communities was generally larger than for soft-sediment habitats. It is hoped that the information provided in this review will be used to guide sustainable environmental management of offshore drilling and production activities in the marine environment. In reviewing the existing literature, a series of research questions regarding the environmental effects of the offshore oil industry that still remain unanswered have also been identified. These include questions on (1) longterm chronic impacts on ecosystems, (2) effects of drilling programmes on deep-sea and hard-bottom habitats and (3) cumulative impacts of oil and gas activities in a marine context. These needs are discussed below, including recommendations regarding management frameworks that could be developed to facilitate decisions when an area is developed for oil production, including how and where exploration and development drilling should be permitted.

This review identifies that there is limited fundamental research to understand long-term chronic impacts of drilling activities on benthic ecosystems. Long-term impacts on marine populations can occur as a consequence of low-level but chronic exposure to petroleum hydrocarbons, drilling fluids, metals and other chemicals associated with drilling activities. A number of mechanisms may operate to impact a given biological community, including chemical toxicity, organic enrichment and physical interference from particles in suspension (Patin 1999, Cranford 2004). An increasing amount of ecotoxicology experiments have been published that research the chemical toxicity of drilling wastes for various organisms in laboratory experiments (see review by Holdway 2002). However, it is generally not possible in the laboratory to investigate and understand the responses of whole ecosystems over the actual time 
Table 4. Summary statistics for all studies providing the distance (m) of elevated sediment contaminants and benthic community change resulting from drilling muds. Data are summarised by spatial zone of influence from greatest to least distance of physical and biological effects. nd: no data

\begin{tabular}{|c|c|c|c|}
\hline $\begin{array}{l}\text { Barium/ } \\
\text { synthet- } \\
\text { ic based } \\
\text { fluids (m) }\end{array}$ & $\begin{array}{c}\text { Total } \\
\text { hydrocar- } \\
\text { bon con- } \\
\text { tent }(\mathrm{m})\end{array}$ & $\begin{array}{l}\text { Biological } \\
\text { change } \\
(\mathrm{m})\end{array}$ & Source \\
\hline \multicolumn{4}{|c|}{ Oil-based fluids } \\
\hline 6000 & 6000 & 6000 & Olsgard \& Gray (1995) - Valhall \\
\hline 4000 & 4000 & 2000 & Olsgard \& Gray (1995) - Gyda \\
\hline 4000 & 4000 & 1000 & Olsgard \& Gray (1995) - Veslefrikk \\
\hline 3000 & 3000 & 3000 & Gray et al. (1990) \\
\hline nd & 3000 & 1000 & Davies et al. (1984) \\
\hline nd & 1000 & 2000 & Mair et al. (1987) \\
\hline nd & No gradien & 1000 & Kröncke et al. (1992) \\
\hline \multicolumn{4}{|c|}{ Water-based fluids } \\
\hline 65000 & nd & No effect & Neff et al. (1989) \\
\hline nd & $\begin{array}{l}700 \text { to } \\
25500\end{array}$ & $\begin{array}{l}\text { Region-wide } \\
\text { effects }\end{array}$ & Hernández Arana et al. (2005) \\
\hline 6000 & nd & nd & Bothner et al. (1985) \\
\hline 4000 & nd & 3700 (Seagrass) & CSA (1988) \\
\hline 4000 & nd & 2000 (Bryozoan) & CSA (1989) \\
\hline 4000 & nd & nd & CSA (1986) \\
\hline 1000 & nd & 1000 & US DOI (1977) \\
\hline 1600 & nd & 150 & Menzie et al. (1980) \\
\hline 500 & nd & 200 & Booth \& Presley (1989) \\
\hline 400 & nd & nd & Houghton et al. (1980) \\
\hline nd & nd & 200 & Currie \& Isaacs (2005) \\
\hline nd & nd & 120 & Manoukian et al. (2010) \\
\hline nd & nd & 100 & Montagna \& Harper (1996) \\
\hline \multicolumn{4}{|c|}{ Synthetic-based fluids } \\
\hline nd & $3000 \mathrm{~N}$ & $\begin{array}{l}\text { Mild stimulatory/ } \\
\text { inhibitory effects }\end{array}$ & DeBlois et al. (2005) \\
\hline 200 & nd & 500 to 1000 & Daan et al. (1996) \\
\hline 1000 & nd & 100 & Schaanning (1995) \\
\hline 200 & 500 & 100 & Smith \& May (1991) \\
\hline 200 & 200 & 50 & Candler et al. (1995) \\
\hline
\end{tabular}

In a review of the long-term consequences of oil and gas production in the Gulf of Mexico, Peterson et al. (1996) argued that our understanding of the consequences of sublethal environmental changes associated with offshore hydrocarbon production is limited. Understanding chronic and sublethal effects on biological communities was also identified as the most important research priority to improve public decision making on proposals to develop additional hydrocarbon resources (Peterson et al. 1996). Further, prominent concerns regarding the ecological consequences of the industry are the longterm consequences of chronic contamination (NRC 1991, 1992, Patin 1999).

Another research gap identified here is the limited knowledge of how oil and gas operations will impact deep-sea habitats. Most studies on the effects of oil and gas operations have been conducted in soft-sediment benthic habitats on continental shelf environments. As oil and gas operations move into deeper waters, the species assemblages and habitats encountered change. There is growing concern that as exploration drilling programmes move into deeper waters, potential interactions with unique hard-bottom and coral habitats are likely to increase (Probert et al. 1997, Reed 2002, Hurley \& Ellis 2004). Deep-water oil reserves have

and spatial scales involved, and it is essential that more holistic and field-based research programmes also be employed to understand ecosystem-level impacts.

Laboratory studies have also been conducted to determine potential long-term effects of particles in suspension on filter-feeding populations. For example, research conducted on scallops indicates that physical interference by bentonite and barite particles in drilling wastes can affect growth and reproduction at environmentally relevant concentrations (Cranford 2004). Benthic boundary layer transport models were used to simulate the dispersion of drilling wastes around drilling platforms under typical exploration drilling scenarios (Hannah et al. 1995, 2006), and concentrations known to affect scallops were predicted to occur over large areas (several $\mathrm{km})$. been identified in the Gulf of Mexico, Brazil, Africa, Atlantic Canada, New Zealand and Arctic regions, and these areas are slated for potential development. While in some regions extensive information is compiled on habitat distributions of key species in these areas, in general there is limited knowledge of the distribution, habitat, age composition and biological aspects of deep-water species such as corals (Mortensen et al. 2002). The greatest concern for coral species from oil and gas activities identified to date is the potential for smothering from drill cuttings (Roberts et al. 2006), and presumably this will also be a major factor for other hard-bottom epifaunal species. Laboratory experiments indicate the potential for polyp mortality caused by drill cuttings (Larsson \& Purser 2011) as well as alterations in feeding behaviours, coral physiology and disruption of calcification (Dodge \& Szmant-Froelich 1985). The tolerance of 
Table 5. Benthic abundance and diversity data taken from Norwegian drilling fields discharging both ether/olefin and ester/olefin syntheticbased fluids (data from Jensen et al. 1999). nd: no data, max.: maximum, ind.: individual

\begin{tabular}{|lcccc|}
\hline Field & Year & $\begin{array}{c}\text { Depth } \\
(\mathrm{m})\end{array}$ & $\begin{array}{c}\text { Max. distance } \\
\text { with reduced } \\
\text { diversity (m) }\end{array}$ & $\begin{array}{c}\text { Change } \\
\text { in ind. } \\
\text { density (m) }\end{array}$ \\
\hline Stratfjord North & 1996 & $260-289$ & 500 & 1000 \\
Stratfjord East & 1997 & $146-207$ & 500 & 1000 \\
Tordis & 1996 & $190-222$ & 250 & 1000 \\
Snorre & 1996 & $294-340$ & 500 & 500 \\
Heidrun & 1997 & $228-350$ & 250 & 550 \\
Balder & 1997 & $120-126$ & 250 & 500 \\
Froy & 1997 & $108-115$ & 250 & 500 \\
Vigdis & 1996 & nd & 250 & 500 \\
\hline
\end{tabular}

individual species to the constituents of drill cuttings has also been found to be highly variable (Rogers 1999). Given the amounts of drilling fluids and cuttings that can be released into the water column from a drilling programme and the knowledge that sedimentation and chemical toxicity are destructive to hard-bottom and coral assemblages, we identify that this is an area requiring careful monitoring and research as oil and gas activities move into these deep-water habitats.

Finally, the cumulative impact of multiple oil and gas operations within a region requires more detailed research. Data collected from EEM programmes are specific to the platform or well being drilled and are usually collected as part of compliance monitoring to ensure the scale of effects does not exceed predictions made in the environmental assessment (EA). However, research to address cumulative impacts is necessary to provide information on factors such as the potential of benthic communities to recover in areas where multiple wells are in operation. We found only 1 study that assessed cumulative impacts of oil and gas activities in a region of multiple wells (Hernández Arana et al. 2005). Stations located in areas of high oil platform densities had significantly lower abundance and biomass and different species assemblage composition than those stations located in areas of low platform densities, and the authors therefore concluded that drilling-related activities affected the area over relatively extensive regional scales. Extensive contaminated areas and overlapping influences from neighbouring oil fields are expected in areas with a long history of oil exploration (Olsgard \& Gray 1995). The regional scale study conducted in the southern Gulf of Mexico supported this assumption (Hernández Arana et al. 2005). The consequences of shifts in spe- cies assemblage composition that have been summarized in this study will require further research to determine impacts at the ecosystem level. The likely ability of benthic communities to recover will also be affected as the scale of disturbed communities becomes larger. Research designed to understand and manage cumulative impacts will become more important as industry activities grow in a region.

Research to assess cumulative impacts will also need to evaluate multiple stressors such as climate change, resource depletion and pollution in a spatial framework in order to fully assess the long-term impacts of oil and gas activities in a marine context. Management focused on impacts of a single stressor is inefficient and often ineffective because co-occurring human activities lead to multiple simultaneous impacts on communities and individual species (Halpern et al. 2008a,b). Therefore, spatial information on human activities and species distribution is needed that can assist in ecosystem-based management decisions. Formalized frameworks to inform management decisions regarding the licensing of exploration and production programmes will also be necessary. Many countries have already developed legislation and frameworks for oil and gas activities operating within their jurisdiction. One example is based on a review of Canadian environmental effects monitoring programmes for exploration drilling which recommended a 'decision tree' process based on 3 scenarios. The scenarios ranged from the situation where no known sensitive habitats are present and where there is sufficient existing information from previous EA work, to the scenario where exploration drilling is slated to occur in sensitive areas (see Hurley \& Ellis 2004). Formalized decision frameworks could be integrated within larger-scale spatial planning approaches to ensure that (1) effects of multiple anthropogenic stressors on the marine environment are considered and, (2) that sensitive habitats are protected when managing the expansion of exploration and production activities within the marine environment.

Acknowledgements. We thank the Social Sciences and Humanities Research Council of Canada (no. 865-20080062) for funding to G.F., and the Habitat Stewardship Program of Environment Canada for funding to the Alder Institute that provided assistance in the preparation of this manuscript. We also thank the 3 anonymous reviewers who provided valuable comments that improved the quality of the manuscript. 


\section{LITERATURE CITED}

Boothe PN, Presley BJ (1989) Trends in sediment trace element concentrations around six petroleum drilling platforms in the northwest Gulf of Mexico. In: Englehardt FR, Ray J, Gillam AH (eds) Drilling wastes. Elsevier Applied Sciences, London, p 3-22

Bothner MH, Rendigs RR, Campbell EY, Doughton MW and others (1985) The Georges Bank monitoring program: analysis of trace metals in bottom sediments during the third year of monitoring. Final report submitted to the U.S. MMS, U.S. DOI, USGS, Woods Hole, MA

Candler JE, Hoskin S, Churan M, Lai CW, Freeman M (1995) Seafloor mapping for synthetic-based mud discharge in the western Gulf of Mexico. Paper presented at the SPE/USEPA exploration and production environmental conference held in Houston, TX, 27-29 March 1995. Cited in: EPA (2000) Environmental assessment of final effluent limitations guidelines and standards for synthetic-based drilling fluids and other non-aqueous drilling fluids in the oil and gas extraction point source category. December Report, EPA-821-B-00-014. United States Environmental Protection Agency, Washington, DC

CSA (Continental Shelf Associates) (1986) Environmental monitoring program for exploratory Well No. 1, Lease OCS-G 6613, East Breaks Area Block 166. Prepared for Texaco USA. Cited in: EPA (2000) Environmental assessment of final effluent limitations guidelines and standards for synthetic-based drilling fluids and other nonaqueous drilling fluids in the oil and gas extraction point source category. December Report, EPA-821-B-00-014. United States Environmental Protection Agency, Washington, DC

CSA (1988) Monitoring of Drillsite A in the Gainesville Area Block 707. Prepared for Sohio Petroleum Company, Houston, Texas. Cited in: EPA (2000) Environmental assessment of final effluent limitations guidelines and standards for synthetic-based drilling fluids and other non-aqueous drilling fluids in the oil and gas extraction point source category. December Report, EPA-821-B-00014. United States Environmental Protection Agency, Washington, DC

CSA (1989) Pre-drilling and post-drilling surveys for Pensacola Area Block 996. Prepared for Texaco Producing Inc. Cited in: EPA (2000) Environmental assessment of final effluent limitations guidelines and standards for synthetic-based drilling fluids and other non-aqueous drilling fluids in the oil and gas extraction point source category. December Report, EPA-821-B-00-014. United States Environmental Protection Agency, Washington, DC

Cranford PJ (2004) Scallops and marine contaminants. In: Shumway SE, Parsons GJ (eds) Scallops: biology, ecology, and aquaculture, 2nd edn. Elsevier, Amsterdam, p 745-764

Cranford PJ, Lee K, Loder J, Milligan TG, Muschenheim D, Payne J (2001) Scientific considerations and research results relevant to the review of the 1996 Offshore Waste Treatment Guidelines. Can Tech Rep Fish Aquat Sci 2364:1-25

> Currie DR, Isaacs LR (2005) Impact of exploratory offshore drilling on benthic communities in the Minerva gas field, Port Campbell, Australia. Mar Environ Res 59:217-233

- Daan R, Boou K, Mulder M, Van Weerlee EM (1996) Environmental effects of a discharge of drill cuttings contam- inated with ester-based drilling muds in the North Sea. Environ Toxicol Chem 15:1709-1722

> Davies JM, Addy JM, Blackman RA, Blanchards JR and others (1984) Environmental effects of use of oil-based drilling muds in the North Sea. Mar Pollut Bull 15: 363-370

Davies JM, Bedborough DR, Blackman RA, Addy JM, Appelbee J, Grogan W, Parker JG, Whitehead A (1988) The environmental effects of oil based mud drilling in the North Sea. UKOOA/Government Working Group to establish and monitor the environmental impacts of offshore oil development in the UK. Elsevier Sciences, New York, NY, p 59-89

DeBlois EM, Lee C, Penney KC, Murdock M, Paine MD, Power F, Williams U (2005) Terra Nova environmental impact effects monitoring program: from environmental impact statement forward. In: Armsworthy SL, Cranford PJ, Lee K (eds) Offshore oil and gas environmental effects monitoring. Battelle Press, Columbus, OH, p 475-491

Dodge RE, Szmant-Froelich A (1985) Effects of drilling fluids on reef corals: a review. In: Duedall IW, Kester DR, Park PK, Ketchum BH (eds) Wastes in the ocean, Vol 4. Wiley Interscience, New York, NY, p 341-364

Duinker PN (1989) Ecological effects monitoring in an environmental assessment: What can it accomplish? Environ Manag 13:797-805

> Ellis JI, Schneider DC (1997) Evaluation of a gradient sampling design for environmental impact assessment. Environ Monit Assess 48:157-172

EPA (United States Environmental Protection Agency) (2000) Environmental assessment of final effluent limitations guidelines and standards for synthetic-based drilling fluids and other non-aqueous drilling fluids in the oil and gas extraction point source category. December Report, EPA-821-B-00-014. United States Environmental Protection Agency, Washington, DC

Fechhelm RG, Gallaway BJ, Farmer JM (1999) Deep-water sampling at a synthetic drilling mud discharge site on the Outer Continental Shelf, Northern Gulf of Mexico. Presented at the 1999 SPE/EPA exploration and production environment conference Feb 28-March 3, 1999. SPE 52744. Society of Petroleum Engineers, Richardson, TX, p 509-513

Gray JS, Clarke KR, Warwick RM, Hobbs G (1990) Detection of initial effects of pollution on marine benthos: an example from the Ekofisk and Eldfisk oil fields, North Sea. Mar Ecol Prog Ser 66:285-299

Green RH (2003) Marine coastal monitoring designs: examples for offshore oil and gas EEM. Offshore oil and gas environmental effects monitoring workshop: approaches and technologies. May 26-29, 2003. Bedford Institute of Oceanography, Dartmouth, Nova Scotia

> Halpern B, Walbridge S, Selkoe K, Kappel C and others (2008a) A global map of human impact on marine ecosystems. Science 319:948-952

Halpern B, McLeod K, Rosenberg A, Crowder L (2008b) Managing for cumulative impacts in ecosystem-based management through ocean zoning. Ocean Coast Manag 51:203-211

Hannah C, Loder J, Shen Y, Muschenheim D (1995) bblt: formulation and exploratory applications of a benthic boundary layer transport model. Can Tech Rep Hydrogr Ocean Sci 166:1-52

Hannah CG, Drozdowski A, Loder J, Muschenheim K, Milligan $T$ (2006) An assessment model of the fate and envi- 
ronmental effects of offshore drilling mud discharges. Estuar Coast Shelf Sci 70:577-588

> Hernández Arana HA, Warwick RM, Attrill MJ, Rowden AA, Gold-Bouchot G (2005) Assessing the impact of oilrelated activities on benthic macroinfauna assemblages of the Campeche shelf, southern Gulf of Mexico. Mar Ecol Prog Ser 289:89-107

Holdway DA (2002) The acute and chronic effects of wastes associated with offshore oil and gas production on temperate and tropical marine ecological processes. Mar Pollut Bull 44:185-203

Houghton JP, Britch RP, Miller RC, Runchal AK (1980) Drilling fluid dispersion studies at the Lower Cook Inlet, Alaska. Proc Symp, Research on Environmental Fate and Effects of Drilling Fluids and Cuttings, January 21-24, 1980. Lake Buena Vista, FL, Vol I, p 285-308

Hurley G, Ellis JI (2004) Environmental effects of exploratory drilling offshore Canada: environmental effects monitoring data and literature review. Prepared for the Canadian Environmental Assessment Agency Regulatory Advisory Committee, Ottawa, Ontario

Husky Oil Ltd (2000) White Rose development environmental comprehensive study, Part I. Husky Oil, St John's, Newfoundland and Labrador

Jenkins KD, Howe S, Saunders BM, Norwood C (1989) Sediment deposition, biological accumulation and subcellular distribution of barium following the drilling of an exploration well. In: Englehardt FR, Ray J, Gillam AH (eds) Drilling wastes. Elsevier Applied Sciences, London, p 587-608

Jensen T, Palerud R, Olsgard F, Bakker S (1999) Dispersion and effects of synthetic drilling fluids on the environment. Biological survey, long-term effect of oil and produced waters, chemicals and oil spill contingency. Report No 99-3507. Prepared for the Norwegian Ministry of Oil and Energy. Olsgard Consulting, Akvaplan-niva and Det Norsk Veritas, London

Kennicutt M, Boothe P, Wade T, Sweet S and others (1996) Geochemical patterns in sediments near offshore production platforms. Can J Fish Aquat Sci 53:2554-2566

Kingston PF (1992) Impact of offshore oil production installations on the benthos of the North Sea. ICES J Mar Sci 49:45-53

Kröncke I, Duineveld GCA, Raak S, Rachor E, Daan R (1992) Effects of a former discharge of drill cuttings on the macrofauna community. Mar Ecol Prog Ser 91:277-287

Larsson AI, Purser A (2011) Sedimentation on the cold-water coral Lophelia pertusa: cleaning efficiency from natural sediments and drill cuttings. Mar Pollut Bull 62: 1159-1168

Lees DC, Houghton JP (1980) Effect of drilling fluids on benthic communities at the Lower Cook Inlet COST Well. Proceedings of symposium, research on environmental fate and effects of drilling fluids and cuttings, January 21-24, 1980. Lake Buena Vista, FL, Vol I, p 209-350

> Mair J, Matheson I, Appelbee J (1987) Offshore macrobenthic recovery in the Murchison field following the termination of drill-cutting discharges. Mar Pollut Bull 18: 628-634

Mariani G, Sick L, Johnson C (1980) An environmental monitoring study to assess the impact of drilling discharges in the Mid-Atlantic. III. Chemical and physical alterations in the benthic environment. Proc Symp, Research on Environmental Fate and Effects of Drilling Fluids and Cuttings, January 21-24, 1980. Lake Buena Vista, FL,
Vol 1, API, Washington, DC, p 438-498

Meek RP, Ray JP (1980) Induced sedimentation, accumulation and transport resulting from exploratory drilling discharges of drilling fluids and cuttings on the southern California Outer Continental Shelf. Proc Symp, Research on Environmental Fate and Effects of Drilling Fluids and Cuttings, January 21-24, 1980. Lake Buena Vista, FL, Vol 1, API, Washington, DC, p 259-284

Menzie C, Maurer D, Leathem W (1980) An environmental monitoring study to assess the impact of drilling discharges in the Mid-Atlantic. IV. The effects of drilling discharges on the benthic community. Proc Symp Research on Environmental Fate and Effects of Drilling Fluids and Cuttings, January 21-24, 1980. Lake Buena Vista, FL, Vol 1, API, Washington, DC, p 499-540

- Manoukian S, Spagnolo A, Scarvella G, Punzo E, Angelini R, Fabi G (2010) Effects of two offshore gas platforms on soft-bottom benthic communities (northwestern Adriatic Sea, Italy). Mar Environ Res 70:402-410

> Montagna PA, Harper DE Jr (1996) Benthic infaunal longterm response to offshore production platforms in the Gulf of Mexico. Can J Fish Aquat Sci 53:2567-2588

Mortensen PB, Buhl-Mortensen L, Gordon DC, Fader GBJ, McKeown DL, Fenton DG (2002) Effects of fisheries on deep-water gorgonian corals in the Northeast Channel, Nova Scotia (Canada). In: Thomas J, Barnes P (eds) Effects of fishing activities on benthic habitats: linking geology, biology, socioeconomics, and management. AFS Symposium, November 12-14, 2002, Tampa, FL, p 369-382

Neff JM (1987) Biological effects of drilling fluids, drill cuttings and produced water. In: Boesch DF, Rabalais NN (eds) Long-term environmental effects of offshore oil and gas development. Elsevier Applied Science, New York, NY, p 469-538

Neff JM (2005) Composition, environmental fates and biological effects of water based drilling muds and cuttings discharged to the marine environment: a synthesis and annotated bibliography. Battelle report to Petroleum Environmental Research Forum (PERF) and American Petroleum Institute, Washington, DC

Neff JM, Bothner M, Maciolek N, Grassle J (1989) Impacts of exploratory drilling for oil and gas on the benthic environment of Georges Bank. Mar Environ Res 27:77-114

NRC (National Research Council) (1991) The adequacy of environmental information for outer continental shelf oil and gas decisions: Georges Banks. National Academy Press, Washington, DC

NRC (1992) Assessment of the U.S. outer continental shelf environmental studies program, II. Ecology. National Academy Press, Washington, DC

Olsgard F, Gray JS (1995) A comprehensive analysis of effects of offshore oil and gas exploration and production on the benthic communities of the Norwegian continental shelf. Mar Ecol Prog Ser 122:277-306

Patin S (1999) The environmental impact of the offshore oil and gas industry. EcoMonitor Publishing, East Northport, NY

Pearson TH, Rosenberg R (1978) Macrobenthic succession in relation to organic enrichment and pollution of the marine environment. Oceanogr Mar Biol Annu Rev 16:229-311

Peterson $\mathrm{CH}$, Kennicutt MC, Green RH, Montagna $\mathrm{P}$, Harper DE, Powell EN, Roscigno PF (1996) Ecological consequences of environmental perturbations associated 
with offshore hydrocarbon production: a perspective on long-term exposures in the Gulf of Mexico. Can J Fish Aquat Sci 53:2637-2654

Probert PK, McKnight DG, Grove SL (1997) Benthic invertebrate bycatch from a deep-water trawl fishery, Chatham Rise, New Zealand. Aquat Conserv 7:27-40

Pulsipher AG, Daniel WB (2000) Onshore disposition of offshore oil and gas platforms: western politics and international standards. Ocean Coast Manag 43:973-995

Ray JP, Meek RP (1980) Water column characterisation of drilling fluids dispersion from an offshore exploratory well on Tanner Bank. Proc Symp, Research on Environmental Fate and Effects of Drilling Fluids and Cuttings, January 21-24, 1980. Lake Buena Vista, FL, Vol 1, p 223-258

Reed JK (2002) Deep-water Oculina coral reefs of Florida: biology, impacts, and management. Hydrobiologia 471: 43-55

Roberts JM, Wheeler AJ, Freiwald A (2006) Reefs of the deep: the biology and geology of cold-water coral ecosystems. Science 312:543-547

Rogers AD (1999) The biology of Lophelia pertusa (Linnaeus 1758) and other deep-water reef-forming corals and impacts from human activities. Int Rev Hydrobiol 84: 315-406

Schaanning MT (1995) Evaluation of overall marine impact of the Novadril Mud System. NIVA Report 0-95018. Norwegian Institute for Water Research, Oslo

Smith J, May SJ (1991) Ula wellsite 7/12-9 environmental survey 1991. A report to SINTEF SI from the field studies council research centre, November. Cited in: EPA (2000) Environmental assessment of final effluent limitations guidelines and standards for synthetic-based drilling fluids and other non-aqueous drilling fluids in the oil and gas extraction point source category. December Report, EPA-821-B-00-014. United States Environmental Protec-

Editorial responsibility: Matthias Seaman,

Oldendorf/Luhe, Germany tion Agency, Washington, DC

Steinhauer M, Imamura E (1990) California OCS phase II monitoring program, year three, annual report. US Department of Interior. Prepared by Battelle Ocean Sciences for Minerals Management Service, Pacific OCS Region. Cited in: EPA (2000) Environmental assessment of final effluent limitations guidelines and standards for synthetic-based drilling fluids and other non-aqueous drilling fluids in the oil and gas extraction point source category. December Report, EPA-821-B-00-014. United States Environmental Protection Agency, Washington, DC

Terlizzi A, Bevilacqua S, Scuderi D, Fiorentino D and others (2008) Effects of offshore platforms on soft-bottom macrobenthic assemblages: a case study in a Mediterranean gas field. Mar Pollut Bull 56:1303-1309

> Trannum HC, Nilsson HC, Schaanning MT, Øxnevad S (2010) Effects of sedimentation from water-based drill cuttings and natural sediment on benthic macrofaunal community structure and ecosystem processes. J Exp Mar Biol Ecol 383:111-121

US DOI (United States Department of Interior) (1977) Baseline monitoring studies, Mississippi, Alabama, Florida, Outer Continental Shelf, 1975-1976. Volume VI. Rig monitoring, assessment of the environmental impact of exploratory drilling. Prepared by the State University System of Florida, Institute of Oceanography. Contract 08550-CT5-30, Bureau of Land Management, Washington, DC

> Warwick RM, Clarke KR (1993) Increased variability as a symptom of stress in marine communities. J Exp Mar Biol Ecol 172:215-226

- Warwick RM, Clarke KR, Suharsono (1990) A statistical analysis of coral community responses to the 1982-83 El Niño in the Thousand Islands, Indonesia. Coral Reefs 8: 171-179

Submitted: March 14, 2011; Accepted: January 25, 2012 Proofs received from author(s): May 23, 2012 